\title{
Pulmonary function after prolonged mechanical ventilation with high concentrations of oxygen
}

\author{
C E GILLBE, J C SALT, AND M A BRANTHWAITE
}

From the Brompton Hospital, London

\begin{abstract}
The mortality and morbidity resulting from mechanical ventilation with high concentrations of inspired oxygen has been investigated in two groups of patients. Ninety-one patients requiring mechanical ventilation for pulmonary disease included six (group 1) in whom death was attributed directly to respiratory failure but only three in whom oxygen toxicity might have been relevant. Review of the clinical and postmortem findings suggests that oxygen was probably not a contributory factor in two of these three. A second group of 16 patients who survived prolonged mechanical ventilation with oxygen in excess of $40 \%$ (average 14.5 days) included five who had been ventilated with $75 \%$ oxygen or more for an average of 38 hours. Lung function studies carried out on this second group of patients approximately one year later demonstrated that all but three had significant defects in either ventilation, gas transfer, or both. Oxygen toxicity was thought to be a likely cause in one and a possible contributory factor in three more. It is suggested that the adverse effects of oxygen on the alveolar epithelium are rarely of practical importance in hypoxaemic patients requiring mechanical ventilation but disturbance to the pulmonary defences against infection may well be of greater importance. The fear of inducing oxygen toxicity should not be allowed to interfere with the relief of arterial hypoxaemia in ventilated patients.
\end{abstract}

The hazards of oxygen toxicity have been publicised widely ${ }^{1-4}$ and adverse effects can be demonstrated in normal subjects after breathing $100 \%$ oxygen at atmospheric pressure for only a few hours. ${ }^{5}$ The pathology of oxygen toxicity is non. specific $^{6}$ and, although it is difficult to demonstrate that treatment with oxygen contributes to mortality in patients who are suffering from respiratory failure already, it has been suggested that concentrations in excess of $40 \%$ are dangerous. ${ }^{7}$

During intermittent positive pressure ventilation (IPPV), high concentrations of oxygen can be delivered continuously for prolonged periods and may be needed if the arterial oxygen tension $\left(\mathrm{PaO}_{2}\right)$ is to be maintained within the normal range. Although some patients can be managed safely with a $\mathrm{PaO}_{2}$ well below the normal range, this is not true in those who are anaemic, or who have a low cardiac output, a high metabolic rate, or impaired renal or cerebral function.

It has been the policy at this hospital to increase

Address for reprint requests: Dr MA Branthwaite, Brompton Hospital, Fulham Road, London SW3 6HP. the inspired oxygen concentration during mechanical ventilation until a $\mathrm{PaO}_{2}$ of approximately $10 \mathrm{kPa}$ is reached if possible; concentrations of $90-100 \%$ oxygen are used without hesitation if necessary. If significant oxygen toxicity has resulted, this might be apparent as mortality during mechanical ventilation or morbidity in those who survive. Attempts to investigate this possibility are reported here.

\section{Methods}

RETROSPECTIVE STUDY OF MORTALITY

An account of 91 patients requiring mechanical ventilation for pulmonary disease at this hospital has been published recently. ${ }^{8}$ All received oxygenenriched air and some required oxygen at concentrations in excess of $75 \%$. Although 32 patients died during IPPV, only six died directly from respiratory failure; the others succumbed to infection, cardiac or renal failure, cerebral damage, or gastrointestinal complications. Death was attributed directly to respiratory failure when either 
hypercapnia $\left(\mathrm{PaCO}_{2} \geqslant 6.8 \mathrm{kPa}\right)$ or hypoxaemia $\left(\mathrm{PaO}_{2} \leqslant 8.0 \mathrm{kPa}\right)$ persisted in spite of mechanical ventilation, with positive end-expiratory pressure when appropriate, and an inspired oxygen concentration of up to $100 \%$. Clinical details of these six patients and the results of postmortem examination where available have been obtained.

PROSPECTIVE STUDY OF MORBIDITY IN SURVIVORS All patients requiring mechanical ventilation for more than two days with more than $40 \%$ oxygen were selected from the adult intensive care unit admission list during a 12-month period. Twentythree survivors (17 males: six females; aged from 14 to 73 years) were contacted and invited to attend for lung function studies. Seven patients did not return for the following reasons: lost to follow-up (two), too disabled to complete the journey because of cardiac, cerebral, or genitourinary disease (three), died since discharge (one), refused (one).

Details of the duration of mechanical ventilation and the inspired oxygen concentration were obtained for each of the remaining 16 patients. Periods of mechanical ventilation with less than $40 \%$ oxygen, and spontaneous ventilation on any concentration of oxygen were discounted. All these patients were studied at least nine months after their discharge from the intensive care unit when measurements were made of vital capacity (VC), forced expired volume in one second $\left(\mathrm{FEV}_{1}\right)$, total lung capacity (TLC; body plethysmograph), and gas transfer (TLCO and KCO; single breath method). Spirometry was repeated after the supervised inhalation of $200 \mu \mathrm{g}$ of salbutamol. Patients were questioned directly about cough, dyspnoea, or sputum production, and about any other physical or psychological disturbances noticed during or after their stay in the intensive care unit. Past and current smoking habits were noted. The results of lung function tests were compared with the predicted range of normal values ${ }^{9}$; tabulated values are expressed as a percentage of the mean of the normal range.

Table 1 Clinical details of six patients who died during mechanical ventilation in whom respiratory failure was the sole or main cause

\begin{tabular}{|c|c|c|c|c|c|c|}
\hline Patient & $\begin{array}{l}\text { Age } \\
(y r)\end{array}$ & $\operatorname{Sex}$ & $\begin{array}{l}\text { Duration } \\
\text { of IPPV }\end{array}$ & $\begin{array}{l}\left(\mathrm{FiO}_{2}\right. \\
\%)\end{array}$ & Clinical diagnosis & Necropsy \\
\hline $\begin{array}{l}\text { EJ } \\
\text { AdS } \\
\text { DT }\end{array}$ & $\begin{array}{l}50 \\
22 \\
29\end{array}$ & $\begin{array}{l}\mathbf{M} \\
\mathbf{F} \\
\mathbf{M}\end{array}$ & $\begin{array}{l}2 \text { days } \\
14 \cdot 5 \text { days } \\
5 \cdot 5 \text { months }\end{array}$ & $\begin{array}{l}60-80 \\
75-95 \\
40-50\end{array}$ & $\begin{array}{l}\text { Asbestosis, myocardial infarction, pulmonary oedema, bronchopneumonia } \\
\text { Pulmonary tuberculosis, immunosuppressed, pneumocystis carinii pneumonia } \\
\text { Mild extrinsic asthma, influenza, obliterative bronchiolitis, bronchiectasis, } \\
\text { lung abscess } \times 2\end{array}$ & $\begin{array}{l}\text { No } \\
\text { Yes } \\
\text { Yes }\end{array}$ \\
\hline $\begin{array}{l}\text { MB } \\
\text { ES } \\
\text { EC }\end{array}$ & $\begin{array}{r}3 \\
59 \\
55\end{array}$ & $\begin{array}{l}\mathbf{F} \\
\mathbf{M} \\
\mathbf{F}\end{array}$ & $\begin{array}{l}15 \text { days } \\
8 \text { days } \\
3 \text { days }\end{array}$ & $\begin{array}{l}70-85 \\
75-100 \\
35-40\end{array}$ & $\begin{array}{l}\text { Acute lymphatic leukaemia in remission, immunosuppressed, influenza A } \\
\text { Fibrosing alveolitis, ?pneumonia } \\
\text { Emphysema, ?influenza }\end{array}$ & $\begin{array}{l}\text { Yes } \\
\text { Yes } \\
\text { No }\end{array}$ \\
\hline
\end{tabular}

\section{Results}

RETROSPECTIVE STUDY OF MORTALITY

Clinical details of the patients who died from respiratory failure during mechanical ventilation ${ }^{\text {s }}$ are given in table 1 . Two died soon after admission $\overrightarrow{0}$ (within two and three days respectively) before $\vec{\omega}$ oxygen toxicity could be a contributory factor. One died after almost six months of mechanical ventilation for obliterative bronchiolitis compli- $-\dot{x}$ cated by bronchiectasis and lung abscesses. $A^{\text {or }}$ minute volume of 16 litres was insufficient to $\vec{N}$ lower the arterial carbon dioxide tension below 0 $7 \cdot 3 \mathrm{kPa}$ but oxygenation was little problem. The ${ }_{\circ}$ remaining three patients died after mechanical ventilation for eight to 15 days with an inspired $\vec{\square}$ oxygen concentration $\left(\mathrm{FiO}_{2}\right)$ of $75 \%$ or more. $\mathbb{Q}$ The postmortem findings in these three patients in $\mathbb{3}$ whom oxygen toxicity might be anticipated areơ presented in table 2 .

PROSPECTIVE STUDY OF MORBIDITY (TABLE 3)

The 16 patients were ventilated with $40 \%$ oxygen or more for periods ranging from 40 to 882 hours, median 272 hours. All required an inspired oxygen concentration of $60 \%$ or more for between 10 and 246 hours (median 114 hours). Nine patients were $\frac{}{Q}$ ventilated with $75 \%$ oxygen or more for part of their illness, and five of these required IPPV with $75 \%$ oxygen or more for between 28 and 48 hours? (median 36 hours). The duration of exposure to these concentrations of oxygen is shown in the figure.

Three of the five patients who required mech- $\frac{\hat{D}}{x}$ anical ventilation with $75 \%$ oxygen or more foro between 28 and 48 hours are in good health now? but two have residual cardiac or pulmonaryô disease. All have impaired gas transfer but the transfer coefficient is reduced in only two, is nor-윽 mal in two, and greater than normal in one.

Six patients who were ventilated for more than three days with an inspired oxygen concentration of between 60 and $75 \%$ include four who are now well, one $(\mathrm{JH})$ who is disabled by cardiac disease, $\mathbb{N}$ 
Table 2 Postmortem findings in three patients in whom oxygen toxicity was suspected

\begin{tabular}{ll}
\hline Patient & Findings \\
\hline AdS & $\begin{array}{l}\text { Areas of fibrosis in three of seven sections; most alveoli full of Pneumocystis carinii; only moderate cellular infiltration of alveolar } \\
\text { walls; areas of cuboidal metaplasia and a few hyaline membranes. }\end{array}$ \\
MB & $\begin{array}{l}\text { Severe interstitial fibrosis; few surviving alveolar spaces which are all small; some alveoli near bronchioles are lined by bronchiolar } \\
\text { epithelium; elsewhere there are prominent type } 2 \text { cells; minimal inflammatory reaction. }\end{array}$ \\
ES & $\begin{array}{l}\text { Pulmonary fibrosis; plump fibroblasts in alveolar walls; mild interstitial infiltrate of lymphocytes and plasma cells; type } 2 \text { cells } \\
\text { increased in number; some hyaline membrane formation and some areas of pulmonary haemorrhage; alveolar cell carcinoma; } \\
\text { pulmonary emboli; H simplex virus isolated. }\end{array}$
\end{tabular}

Table 3 Clinical details and results of lung function studies in 16 surviving patients.

Upper panel: patients ventilated with $75 \%$ oxygen or more for at least 24 hours.

Middle panel: patients ventilated with $60 \%$ oxygen or more for at least three days.

Lower panel: patients ventilated with $60 \%$ oxygen or more for less than three days

\begin{tabular}{|c|c|c|c|c|c|c|c|c|c|c|}
\hline Patient & $\begin{array}{l}\text { Age } \\
(y r)\end{array}$ & Diagnosis & Health at follow-up & $\begin{array}{l}\text { Hours } \\
>40 \%\end{array}$ & $\begin{array}{l}I P P V \\
>60 \%\end{array}$ & $\begin{array}{l}\text { At } \\
>75 \%\end{array}$ & $\begin{array}{l}F E V_{1} / \\
F V C \%\end{array}$ & $\begin{array}{l}T L C \\
\text { (\% pre }\end{array}$ & $\begin{array}{r}T_{L C O} \\
\text { edicted })\end{array}$ & $K(0$ \\
\hline NR & 46 & $\begin{array}{l}\text { Ischaemic heart disease; severe left } \\
\text { ventricular failure after operation; } \\
\text { IABP }\end{array}$ & $\begin{array}{l}\text { Poor; late postoperative } \\
\text { pneumonia + pleural } \\
\text { effusion; residual angina } \\
\text { and left ventricular failure }\end{array}$ & 334 & 114 & 48 & $64 \dagger$ & 90 & $39 \dagger$ & $51 \dagger$ \\
\hline${ }^{*} \mathrm{MG}$ & 56 & $\begin{array}{l}\text { Mixed mitral valve disease; mitral } \\
\text { valve replacement; postoperative } \\
\text { cardiac arrest; septicaemia }\end{array}$ & Good & 124 & 70 & 46 & 77 & $74 \dagger$ & $76 \dagger$ & 98 \\
\hline FP & 58 & $\begin{array}{l}2^{\circ} \text { atrial septal defect; pulmonary } \\
\text { hypertension; chronic airways } \\
\text { obstruction; postoperative respiratory } \\
\text { and renal failure }\end{array}$ & Excellent & 747 & 105 & 36 & $50 \dagger$ & 94 & $82 \dagger$ & $128 \ddagger$ \\
\hline IW & 56 & $\begin{array}{l}\text { Ischaemic heart disease; left } \\
\text { ventricular aneurysm; severe left } \\
\text { ventricular failure after operation; } \\
\text { IABP }\end{array}$ & $\begin{array}{l}\text { Good; ? one attack of } \\
\text { anginal pain }\end{array}$ & 228 & 129 & 31 & $69 \dagger$ & 105 & $72 \dagger$ & $83 \dagger$ \\
\hline *RO & 58 & $\begin{array}{l}\text { Pulmonary tuberculosis; cirrhosis; } \\
\text { bronchopneumonia; cardiac arrest; } \\
\text { ? pulmonary embolism }\end{array}$ & $\begin{array}{l}\text { Poor; dense hemiplegia } \\
\text { sustained during recovery }\end{array}$ & 643 & 246 & 28 & 67 & $64 t$ & $50 \dagger$ & 86 \\
\hline JJ & 67 & $\begin{array}{l}\text { Ischaemic heart disease; chronic } \\
\text { bronchitis; severe postoperative left } \\
\text { ventricular failure; renal failure; IABP }\end{array}$ & $\begin{array}{l}\text { Good; intermittent } \\
\text { claudication }\end{array}$ & 345 & 236 & 0 & 76 & 94 & $73 \dagger$ & 99 \\
\hline JH & 24 & $\begin{array}{l}\text { Transposition of the great vessels; } \\
\text { ventrical septal defect and } \\
\text { pulmonary stenosis; pulmonary } \\
\text { vascular disease }\end{array}$ & $\begin{array}{l}\text { Poor; congestive heart } \\
\text { failure and right pleural } \\
\text { effusion }\end{array}$ & 597 & 125 & 3 & $73 \dagger$ & $53 \dagger$ & $48 \dagger$ & 102 \\
\hline WG & 73 & $\begin{array}{l}\text { Severe calcific aortic stenosis; } \\
\text { postoperative left ventricular failure; } \\
\text { bronchopneumonia }\end{array}$ & Good; mild ataxia & 882 & 116 & 0 & $72 \ddagger$ & 101 & $75 \dagger$ & $83 \dagger$ \\
\hline JF & 61 & $\begin{array}{l}\text { Ischaemic heart disease; post- } \\
\text { operative left ventricular failure }\end{array}$ & Very good; ventral hernia & 184 & 115 & 0 & 66 & 106 & 92 & 114 \\
\hline JS & 56 & $\begin{array}{l}\text { Bulbar palsy; lung abscess; } \\
\text { empyema; bronchopleural fistula; } \\
\text { bilateral cavitating pneumonia }\end{array}$ & $\begin{array}{l}\text { Good; residual ataxia } \\
\text { and visual defect }\end{array}$ & 592 & 113 & 0 & $81 \ddagger$ & $73 \dagger$ & $65 \dagger$ & 93 \\
\hline AS & 57 & $\begin{array}{l}\text { Ischaemic heart disease; post- } \\
\text { operative cardiac and respiratory } \\
\text { failure }\end{array}$ & $\begin{array}{l}\text { Dyspnoea worse than } \\
\text { before operation but } \\
\text { angina totally relieved }\end{array}$ & 325 & 82 & 0 & $47 \dagger$ & 107 & $38 \dagger$ & $39 \dagger$ \\
\hline EW & 58 & $\begin{array}{l}\text { Aortic and mitral valve disease; } \\
\text { pre and postoperative severe left } \\
\text { ventricular failure; IABP }\end{array}$ & $\begin{array}{l}\text { Good; claudication } \\
\text { probably a sequel to } \\
\text { aortic counter-pulsation }\end{array}$ & 228 & 47 & 0 & $62 \dagger$ & $128 \ddagger$ & $76 \dagger$ & $77 \dagger$ \\
\hline JE & 22 & Pneumococcal pneumonia & Excellent & 86 & 45 & 3 & 81 & 92 & 90 & 94 \\
\hline EH & 56 & $\begin{array}{l}\text { Ischaemic heart disease; severe } \\
\text { left ventricular failure both before } \\
\text { and after operation; IABP }\end{array}$ & $\begin{array}{l}\text { Poor; all symptoms } \\
\text { worse than before } \\
\text { operation }\end{array}$ & 65 & 33 & 1 & $83 \dagger$ & $76 \dagger$ & 106 & $165 \dagger$ \\
\hline PW & 44 & $\begin{array}{l}\text { Ischaemic heart disease; pre and } \\
\text { postoperative left ventricular } \\
\text { failure; 1ABP }\end{array}$ & $\begin{array}{l}\text { Poor; worse than before } \\
\text { operation; cardiac failure; } \\
\text { polyarthritis; ? systemic } \\
\text { lupus erythematosis; }\end{array}$ & 42 & 15 & 5 & 74 & $66 \dagger$ & $44 \dagger$ & $73 \dagger$ \\
\hline JB & 14 & Severe acute asthma & Excellent & 40 & 10 & 0 & $61 \dagger$ & 110 & 109 & 110 \\
\hline
\end{tabular}

*TLC could not be determined by plethysmography in MG and RO; figures for these two patients relate to measured and predicted alveolar volume determined by helium rebreathing during measurement of gas transfer

IABP $=$ intra-aortic balloon pump

†Value below predicted lower limit of normal

$\$$ Value above predicted upper limit of normal 


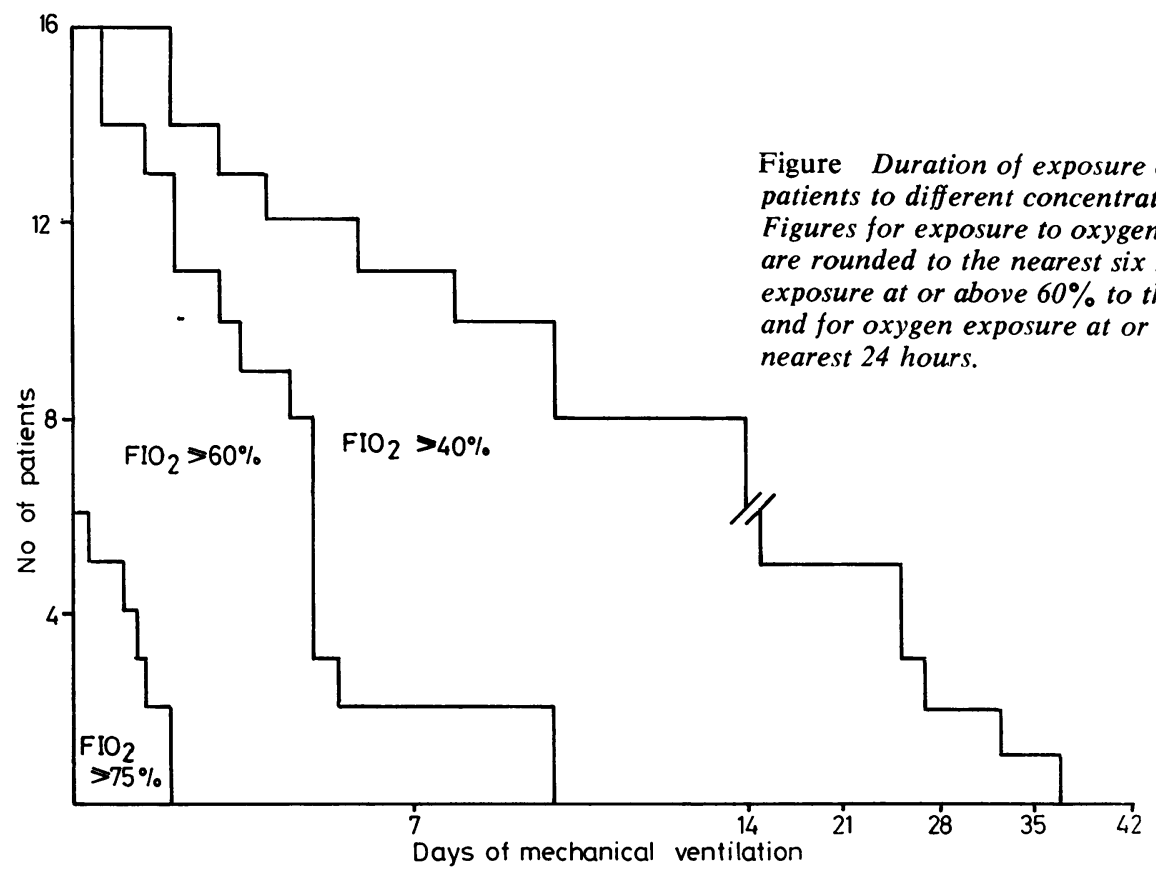

and one (AS) whose anginal pain has been relieved by operation but who is more dyspnoeic than before. One patient (JF) has normal lung function in spite of 115 hours mechanical ventilation with $60-75 \%$ oxygen. The remaining five have impaired gas transfer but the transfer coefficient is reduced in only two, including the patient whose dyspnoea is worse than before operation.

Five patients who required mechanical ventilation with $60-70 \%$ oxygen for less than three days include two (EH and PW) disabled by cardiac disease both before and after operation, and three who are now in good health. Two of the three in good health have normal (JE) or near normal (JB) pulmonary function; the third (EW), with aortic and mitral valve disease complicated by preoperative left ventricular failure, still has evidence of airflow limitation with impaired gas transfer and a reduced transfer coefficient.

Only two patients in the entire group are nonsmokers (JB and JS).

\section{Discussion}

Mechanical ventilation with high concentrations of inspired oxygen is only required for patients with severe cardiac or pulmonary disease, many of whom are likely to have impaired pulmonary function as a result of their disease and inde- pendent of its treatment. The disorders from which $\triangle$ they suffer are diverse, life-threatening, and acute $\overrightarrow{\overrightarrow{0}}$ and so there are few opportunities for controlled 3 observation and comparison. In spite of these limitations, it is worth attempting some assessment of the role of oxygen toxicity to ensure that anxiety based on the results of studies in normal subjects or other animal species does not interfere $\stackrel{\tilde{x}}{x}$ with the relief of arterial hypoxaemia when this $\frac{0}{3}$ is needed.

Two groups of patients have been studied in the present series. The first consisted of nearly 100 patients requiring mechanical ventilation for pul- 은 monary disease. Death during mechanical ventila- $\rightarrow$ tion could be attributed directly to respiratory failure in only six and, in three of these, oxygen $N$ toxicity can be disregarded because death occurred $N$ before the effects of oxygen could develop or was $\stackrel{\mathcal{N}}{\mathrm{N}}$ attributable to damage to the airways rather than to the alveoli. The remaining three patients were at greater risk of oxygen toxicity. The first was $\stackrel{\circ}{\subset}$

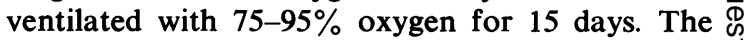
arterial oxygen tension varied between 6 and $7 \mathrm{kPa}$. throughout in spite of mechanical ventilation with an optimum positive end-expiratory pressure of $\overrightarrow{\mathbb{D}}$ $15 \mathrm{~cm} \mathrm{H}_{2} \mathrm{O}$ determined by measurement of pul- $\frac{\rho}{\mathrm{O}}$ monary compliance, ${ }^{10}$ and of the oxygen content in arterial and mixed venous blood. Death occurred within an hour of reducing the positive 
end-expiratory pressure from 15 to $5 \mathrm{~cm}_{2} \mathrm{O}$. Treatment with pentamidine and high-dose cotrimoxazole had been continued for 16 days but, at postmortem, most alveoli were full of Pneumocystis carinii. Although some of the changes listed in table 2 may reflect the effects of oxygen on the lung, the cause of death must be regarded as pneumonia caused by Pneumocysis carinii which had failed to respond to vigorous treatment. Similarly with the second of these three cases, the presence of extensive fibrosing alveolitis, an alveolar cell carcinoma, pulmonary embolism, and pulmonary haemorrhage (the terminal event complicating whole-body heparinisation to permit plasmapheresis), provides sufficient cause for death although, here too, hyaline membrane formation may have represented the effects of oxygen on the lung. It is only in the third of the three fatal cases that a reasonable case can be made for oxygen toxicity as a factor causing or contributing to death. However, extensive fibrosis with small alveoli containing prominent type 2 cells is a nonspecific picture seen in fatal cases of acute respiratory failure treated with no more than $40 \%$ oxygen, as well as in animals exposed to high concentrations of oxygen. ${ }^{11}$

It is also difficult to separate the effects of oxygen from those of disease in the surviving patients but three (JF, JE, and JB) do have virtually normal lung function in spite of mechanical ventilation with $60 \%$ oxygen or more for between 10 and 115 hours. Three more patients $(\mathrm{JH}, \mathrm{EH}$, and $\mathrm{PW}$ ) have grossly disordered lung function after prolonged mechanical ventilation but any effect of oxygen cannot be distinguished from the consequences of their disease.

The five patients ventilated with $75 \%$ oxygen or more for between 24 and 48 hours warrant particular attention. A restrictive ventilatory defect and decreased gas transfer might be expected if there is pulmonary fibrosis caused by oxygen exposure. Three of the five patients show these features but the presence of mitral valve disease, chronic fibrocaseous pulmonary tuberculosis, and heart failure respectively must be partly if not wholly responsible. Similarly the findings in the patient with chronic airways obstruction and pulmonary hypertension secondary to a secundum atrial septal defect could all reflect functional damage caused by these two conditions. Such a conclusion is questionable in IW, a 56-year-old smoker with ischaemic heart disease and preoperative left ventricular failure who required mechanical ventilation and aortic counter-pulsation for severe left ventricular failure after coronary arterial surgery and excision of a ventricular aneurysm. She subsequently made an excellent recovery and was virtually symptom-free at the time of follow-up, apart from one doubtful attack of anginal pain precipitated by severe exertion. The effects of left ventricular failure on pulmonary function are prolonged ${ }^{12}$ and this patient, who still smokes, also has evidence of airflow limitation. However, the reduction in gas transfer is striking, and greater than might be expected on the basis of airflow limitation alone, so the possibility that this represents the additional effect of oxygen toxicity must be accepted.

The findings in patients JS and EW are consistent with the likely outcome of their disease. Patient AS has severe airflow limitation and impaired gas transfer but the total lung capacity is within the normal range. This suggests restriction as well as an obstructive defect as does the shape of a flow-volume trace recorded at the time of follow-up. Fibrosis after oxygen exposure is a possible explanation for these findings. Patient $\mathrm{JJ}$ is a smoker with a history of chronic bronchitis. $\mathrm{He}$ has a normal $\mathrm{FEV}_{1} \%$ and total lung capacity but does have some air trapping: the alveolar volume determined by rebreathing is 1.3 litres less than the total lung capacity determined by plethysmography. The reduction in gas transfer is marked and, although mild airflow limitation may contribute to this, another factor such as the effect of oxygen seems likely. Finally, WG, a 73-year-old man who required almost 37 days IPPV with oxygen concentrations of $40 \%$ or more to control left ventricular failure and subsequent bronchopneumonia after aortic valve replacement, has lungs of normal volume but with an abnormally high ratio of $\mathrm{FEV}_{1}$ to $\mathrm{FVC}$ and significantly reduced gas transfer. He had suffered from anginal pain and dyspnoea on exertion for more than 10 years preoperatively but had no clinical or radiological evidence of left ventricular failure before surgery. Residual heart failure may be responsible for the abnormalities of pulmonary function which have been recorded but there is no clinical or radiological evidence of this now, and he has no pain, syncope, or dyspnoea after walking a mile. In this patient, the residual effects of oxygen toxicity appear the most likely explanation for his reduced gas transfer and mild restrictive defect.

Thus in the study of mortality during mechanical ventilation, oxygen toxicity can be accepted as a possible factor contributing to only one of six deaths related directly to respiratory failure. In 16 patients surviving prolonged mechanical ventilation with high concentrations of oxygen, only 
one patient has a disturbance which can be attributed most easily to the effects of oxygen. The functional disturbances in three more might be explained in part by the effects of oxygen but at least three subjects have survived without demonstrable interference with pulmonary function, or with a mild defect which cannot be attributed to oxygen.

Protection by previous pulmonary injury against the toxic effects of oxygen has been demonstrated experimentally, ${ }^{13}$ and survival after prolonged mechanical ventilation with high concentrations of oxygen has also been reported. ${ }^{14}$ The apparent immunity conferred by arterial hypoxaemia against the toxic effects of oxygen on the lungs may be important, ${ }^{5}$ although greatest protection is afforded against oxygen at more than atmospheric pressure. The induction of protective enzymes by intermittent exposure to high concentrations of oxygen before sustained exposure, ${ }^{15}$ or by the administration of endotoxin ${ }^{16}{ }^{17}$ are other mechanisms which might be relevant clinically.

Apart from the one death in which oxygen toxicity may have contributed to the fatal outcome, the findings reported here support the view that high concentrations of oxygen can be used if necessary during mechanical ventilation without subjecting patients to unreasonable risks of pulmonary damage. It must be remembered, however, that pulmonary infection, particularly with Gram-negative organisms, is one of the most common causes of death in patients requiring intensive care. ${ }^{18} 19$ Experimental studies in rats have demonstrated that prolonged exposure to high concentrations of oxygen alters the flora of the upper respiratory tract (but not of the bowel) from predominantly Gram-positive to predominantly Gram-negative organisms, ${ }^{20}$ and impaired metabolic but not phagocytic activity of rabbit alveolar macrophages has been reported after the intact animal has breathed oxygen for 48-72 hours. ${ }^{21}$ Adverse effects on ciliated epithelium in mice, ${ }^{22}$ on tracheal mucus flow in cats, ${ }^{23}$ and reddening of the trachea with a reduction in the velocity of tracheal mucus flow in $\operatorname{man}^{24}$ have all been described after exposure to oxygen during acute or chronic studies. Mechanical ventilation with high concentrations of oxygen is not without risk but the hazards of infection and of defective clearance of bronchial secretions may well be of far greater importance than the effects of the gas on alveolar epithelium.

We are grateful to the British Heart Foundation, and the Board of Governors of the National Heart and Chest Hospitals for financial support, to the을 physicians and surgeons of the Brompton Hospital $\frac{\bar{s}}{\sigma}$ who allowed us to follow up patients under their care, and to Dr D Denison and the staff of theg Lung Function Laboratories for their willing cooperation and help.

\section{References}

1 Clark JM, Lambertsen CJ. Pulmonary oxygencw toxicity: a review. Pharmacol Rev 1971; 23:37-133.

2 Kafer ER. Pulmonary oxygen toxicity: a review\& of the evidence for acute and chronic oxygen toxicity in man. Br J Anaesth 1971; 43:687-95.

3 Clark JM. The toxicity of oxygen. Am RevRespir Dis 1974; 110: (Suppl) 40-50.

4 Katzenstein LA, Bloor CM, Leibow AA. Diffuse alveolar damage - the role of oxygen, shock, and related factors. Am J Pathol 1976; 85:210-22.

5 Winter PM, Smith G. The toxicity of oxygen. Anesthesiology 1972; 37:210-41.

6 Pratt PC. Pathology of pulmonary oxygen̊ toxicity. Am Rev Respir Dis 1974; 110: (Suppl)b 51-7.

7 Sevitt S. Diffuse and focal pneumonitis: a pre-liminary report on the threshold of pulmonaryo oxygen toxicity in man. J Clin Pathol 1974; 27:0 21-30.

8 Petheram IS, Branthwaite MA. Mechanical ventilation for pulmonary disease: a six year survey. Anaesthesia 1980; 35:467-73.

9 Cotes JM. Lung Function: assessment ant application in medicine. Fourth edition. Oxford: Blackwell Scientific Publications, 1979.

10 Suter PM, Fairley HB, Isenberg MD. Optimum end-expiratory pressure in patients with acute pulmonary failure. $N$ Engl J Med 1975; 292:0 284-9.

11 Bachofen M, Weibel ER. Basin pattern of tissueo repair in human lungs following unspecific injury? Chest 1974; 65: (Suppl) 14S-19S.

12 McNicol MW, Kirby BJ, Bhoola KD, Fulton PM, Tattersfield AE. Changes in pulmonaryo function 6-12 months after recovery from myo cardial infarction. Lancet 1966; 2:1441-3.

13 Winter PM, Smith G, Wheelis RF. The effect of prior pulmonary injury on the rate of develop? ment of fatal oxygen toxicity. Chest 1974; 66: Suppl 1S-4S.

14 Hedley-White J. Control of the uptake of oxygenco $N$ Engl J Med 1968; 279:1152-8.

15 Kimball RE, Reddy K, Peirce TH, Schwartz LW, Mustafa MG, Cross CE. Oxygen toxicity:0 augmentation of antioxidant defence mechanisms in rat lung. Am J Physiol 1976; 230:1425-31.

16 Frank L, Yam J, Roberts RJ. The role of endo $\frac{?}{\mathrm{D}}$ toxin in protection of adult rats from oxygen 0 induced lung toxicity. J Clin Invest 1978: 61: 269-75. 
17 Frank L, Summerville J, Massaro D, Roberts RJ. Protection from the acute and chronic manifestations of pulmonary oxygen toxicity with endotoxin treatment. (Abstract.) $A m R e v$ Respir Dis 1979; 119: No 4 Suppl 113.

18 LaForce FM, Eickoff TC. The role of infection in critical care. Anesthesiol 1977; 47:195-202.

19 Editorial. Multiple organ failure. Lancet 1977; 2:72-3.

20 Paegle RD, Tewari RP, Bernhard WN, Peters E. Microbial flora of the larynx, trachea, and large intestine of the rat after long-term inhalation of $100 \%$ oxygen. Anesthesiology 1976; 44:287-90.

21 Fisher AB, Diamond S, Mellen S, Zubrow A.
Effect of 48- and 72-hour oxygen exposure on the rabbit alveolar macrophage. Chest 1974; 66: Suppl 4S-7S.

22 Obara H, Sekimoto M, Iwai S. Alterations to the bronchial and bronchiolar surfaces of adult mice after exposure to high concentrations of oxygen. Thorax 1979; 34:478-85.

23 Laurenzi GA, Yin S, Guarneri JJ. Adverse effects of oxygen on tracheal mucus flow. $N$ Engl J Med 1968; 279:333-9.

24 Sackner MA, Landa J, Hirsch J, Zapata A. Pulmonary effects of oxygen breathing: a six-hour study in normal men. Ann Intern Med 1975; 82: 40-3.

The Seventh Asia-Pacific Congress on Diseases of the Chest will be held in Hong Kong from 1-5 November 1981. The Congress is sponsored by The International Academy of Chest Physicians and Surgeons affiliated with The American College of Chest Physicians. The scientific programme will include plenary sessions, symposia, sessions for free papers, guest lectures, and round table discussions on all subjects of interest to chest physicians, cardiologists, cardiovascular and thoracic surgeons, cardiopulmonary pathologists, and radiologists. Correspondence concerning the Congress should be addressed to Dr Panna Lal Nandi, Secretary-General, VII Asia-Pacific Congress on Diseases of the Chest, The Grantham Hospital, Aberdeen, Hong Kong. 